\title{
Notas sobre a nevralgia ${ }^{1}$
}

Eduardo Milán

Poeta (Uruguai/México)

RESUMO: TRATA-SE DE DILUCIDAR, A PARTIR DA EXPERIÊNCIA DE DESRADICALIZAÇÃO DA ARTE EM GERAL E DA POESIA EM PARTICULAR, DESDE MEADOS DO SÉCULO XX, PRINCÍPIOS DA DÉCADA DE 50 (NA AMÉRICA LATINA, DESDE A IRRUPÇÃO DA POESIA CONCRETA BRASILEIRA E DA PUBLICAÇÃO DE "POEMAS Y ANTI-POEMAS", DE NICANOR PARRA), QUE SENTIDO ADQUIRE A POESIA MULTIFORMAL E QUANTITATIVA QUE SE ESCREVE NA ATUALIDADE, EM FACE DO PRESENTE ESTÉTICO E DA PRECISA ENCRUZILHADA HISTÓRICA QUE VIVE O MUNDO.

ABSTRACT: THE MAIN OBJECTIVE IS TO ELUCIDATE THE MEANING ACQUIRED BY THE QUANTITATIVE AND MULTIFORM-POETRY THAT IS BEING WRITTEN TODAY CONSIDERING CONTEMPORARY AESTHETICS AND THE PRECISE HISTORICAL CROSSROADS IN PRESENT DAY WORLD. THIS WILL BE DONE BY CONSIDERING THE EXPERIENCE OF THE DE-RADICALISATION OF ART AND POETRY FROM THE MID TWENTIETH CENTURY ONWARDS, FOR EXAMPLE IN LATIN AMERICA, SINCE THE 1950S, FOLLOWING THE BREAKTHROUGH OF CONCRETE POETRY IN BRAZIL AND THE PUBLICATION OF "POEMAS Y ANTI-POEMAS" BY NICANOR PARRA.

PALAVRAS-CHAVE: RADICALIZAÇÃO - DESRADICALIZAÇÃO - ARTE - POESIA - FORMA - MULTIFORMA - ESTÉTICA - HISTÓRIA - MUNDO KEY-WORDS: RADICALISATION - DE-RADICALISATION - ART - POETRY - FORM - MULTIFORM - AESTHETICS - WORLD HISTORY

1 Traduzido por Danilo Bueno e revisado por Horácio Costa. 
Não se sustenta a postura de "a vanguarda como mau momento" da poesia ocidental. A vanguarda é a autonomia da arte participando do social, o anti-Orfeu, o contrário de uma solidão escura: um giro da cabeça para desaparecer não o que olha, senão $o$ que olha. Não posso mais ver as vanguardas - incluindo as históricas - como precisas formações estético-artísticas: cubismo, dadaísmo, futurismo, etc., senão como processo: o momento estético-histórico que permite as legitimações e inclusive as reformulações da arte, ou seja, o que chamamos, precisamente, vanguarda. Sem esse "mau momento" nosso presente seria péssimo. Ou seja, pior que mau. Agora é mau. A razão é simples: não há maneira de saber o que é bom. Tudo está legitimado de antemão, entre outras coisas, pela crise da modernidade e pelo fim das vanguardas. A coexistência de toda possibilidade formal do repertório ou dos repertórios da poesia ocidental é uma das razões da confusão reinante entre os produtores e os críticos, ainda que ambos, por um pragmatismo obseqüente com a duração, custe o que custar, tendam a aceitar o que vier, fizer-se ou ler-se, e de qualquer maneira. Em tempos como o atual, a tendência geral é manter o equilíbrio, certa maneira tolerável de exercer um ofício que já não se pergunta seriamente por si mesmo senão como cacoete autoparódico, um ofício morto no século XIX e várias vezes revivido um século depois. A filosofia - uma certa, claro está, toda filosofia romântica alemã - matou a poesia por disfuncional, e no século seguinte certa filosofia alemã reviveu a poesia como única possibilidade real de sair de um impasse não só filosófico, mas cultural e civilizatório. Heidegger, e não Adorno: este último pôs os pingos nos is. Não vou continuar este relato para render homenagem à tão freqüentemente mencionada ausência de relatos legitimadores. O que me preocupa é que a maioria dos poetas latino-americanos que hoje escrevem não se preocupa em saber sequer o que se passou no dia em que morreu a poesia e muito menos nos diferentes dias nos quais ela renasceu. Isso é grave, porque assim se opera um efeito de ruptura ou ao menos de suspensão: há uma falta de memória entre as gerações anteriores - digamos, desde a dos nascidos nos anos 50, que entroncava ainda com as gerações das primeiras décadas do século, com as quais não mantinham problemas de caracterização, de ânimo ou de âmbito de ação - e as últimas gerações, às quais pouco parece importar a história recente da poesia. 
2. Retorno ao tema existencial. A hipoteca da vida esperada como uma forma idônea de existência está fora de questão. Trata-se da sobrevivência. A situação do mundo atual dá um pouco menos do que nunca para o cultivo de uma arte mais lateral, e devido a isso mesmo a ponto de se transformar em objeto-de-culto-de-cultivo. Pode meditar-se a música de rock, ainda que difícil isso seja quando se tratar de futebol; ambos são segmentos da indústria cultural atual que, por certo, não tardará em confundir ambas essas manifestações ao som de um mesmo desfile estetizado. Não deixa de ser pouco pensável, por outro lado, a meditação da poesia como representação espetacular. Se o poeta se converte em objeto de culto por sua "ciência de cultivo", nada terá que fazer diante da câmera e sob os refletores: salvo ao amparo de uma lógica totalitária, não são comparáveis as potências possíveis de escuta que manifestam a palavra e a música, ainda que possam acompanhar-se ocasionalmente com maior ou menor pertinência. Há música-massa; palavra-massa é somente política, nunca poética. Falo, claro está, em termos culturais estratégicos e não ocasionais: nada nega a possibilidade de uma aparição da palavra poética em qualquer cenário presente. Sua eficácia, no entanto, seria fantasmática, e segue sendo difícil a encenação do espectro, a menos que se considere o espetáculo atual - todo espetáculo atual pertencente ao domínio semântico, mas também formal-decorativo, do "espectral". Se isso é assim - a inserção bloqueada do poeta na "espetacularização da vida" -, tal indicação dirige-se à arte por separado. E é aqui que aparece para mim o grande problema do presente poético em relação à função da poesia e com o possível desenvolvimento da arte desde o início dos séculos "dada por morta". O problema é o que está sucedendo: a consideração da poesia como linguagem específica devido unicamente à sua mera sobrevivência em um mundo ameaçante onde o poético, com sua carga mítico-simbólica, está fora de consideração. Isso, a poesia como "coisa em si" em um mundo poeticamente adverso, obrigaria o regresso a uma normatividade sobre o que fazer poético, a uma certa regulação da prática que serviria para assegurar a sua duração. É óbvio que se a poesia revela seu estado crítico permanente, se coloca em uma posição frágil quanto a uma possível consistência em sua recepção, garantia de permanência, se por acaso ela houver. Uma "poesia de receptor cativo" tem assegurada sua existência em um mundo mais ou 
menos controlado. E se for o caso - e tudo indica que será - de um maior ajuste global dos dispositivos de controle (espécie de revisão exaustiva dos ordálios e ritos de passagem na vida diária), uma poesia sem perturbação e que não perturbe se colocaria em um lugar cultural entre médio e alto - sem descontar a possibilidade de um populismo poético, a divisão da poesia entre as classes marginalizadas como pãezinhos recém-saídos do forno -, posições intercambiáveis dentro da recepção "normal", dada a queda de nível experimentada na indústria cultural nas últimas décadas em relação aos produtos outrora considerados "especializados". Essa hipótese de trabalho, que em certas latitudes já é uma realidade - Enzensberger não existiria, caso contrário -, muda radicalmente (no sentido em que afiança uma tendência) a posição da poesia, seu "lugar" na sociedade - permitindo assim, inclusive, homologar estratos de posição social e de recepção - em relação do que representou o século XX: o passo de uma radicalidade negativa nas primeiras décadas até o culto de uma cotidianidade "menor", de acompanhamento de vida, política de recuperação de certas latitudes vitais esquecidas pelos discursos poéticos dominantes - mesmo que críticos e contraditórios - desde o romantismo e o simbolismo do século XIX, que, ainda que pudessem divergir, enquanto significados, pelos diferentes estados poético-formais, não ocultam sua realidade discordante de uma ordem social estabelecida. Essa realidade afiançaria uma posição inofensiva da prática poética.

3. Na América Latina a situação anterior se aprofunda no sentido negativo, por um lado. Por outro, certa desfiliação - não sei se chamá-la de irresponsável - do impacto dos acontecimentos do presente global, que também são nossos, ainda que não ocorram diretamente entre nós, permite ao poeta latino-americano escapar da "zona de influência" na recepção cultural e poética. O que em outros momentos do século passado - no Brasil, Oswald de Andrade, Haroldo de Campos, Augusto de Campos, Paulo Leminski, para nomear uns poucos - foi desobediência à recepção mesma, tangencialidade, torcedura como resistência, "antropofagia cultural", no presente se manifesta como distanciamento da crise desse logos que já não nos importa como se chama e que figura tenha adquirido, e da civilização que rege e que possibilita - esse estar de novo "fora" como nos bons 
tempos de intempérie, digamos, desde meados do século XIX ou desde o eclipse de Hölderlin, ou nele propriamente dito - quase por flutuação na sopa das formas e das objetividades (subjetivas, valha a brincadeira). Estaríamos falando de uma posição consciente de sua inacessibilidade às rotas de circulação. Isso é importante: ainda que a América Latina agora seja um eixo de conexão virtual, como aparente ruptura da incomunicabilidade de nossa poesia que na década de 80 - quando escrevi uma coluna na revista Vuelta que tratou de abolir aquele acaso que não era acaso senão incomunicabilidade poética, valha de novo a brincadeira - era uma verdadeira fenda por onde caíam livros e plaquetes e impressos, também é certo que essa conexão, hoje sempre ameaçada pelos hackers mais fixos do que ambulantes, não é garantia de nada, salvo de conexão: o nível de discernimento não variou, a cultura poética dita assim, em seu sentido tão agrícola, está em mãos de universidades que estão em mãos de representações - ou mesmo o são - óbvias de poder. A poesia que circula midiaticamente é quase um oxímoro em termos míticos. Haveria de saber o que representa um poeta midiaticamente considerado. Não se trata, é claro, de um problema de suportes nem de um "fora do lugar" tecnológico. Trata-se de verificar uma vez mais a posição a que se chega quando se habita um lugar meramente midiático: que é um poeta quando vive em um meio que não é ambiente senão que, uma vez que influi em sua consideração, o atravessa. Não há uma casa dos mídia ainda que os mídia estejam em casa. A liberdade de sair e de entrar dos mídia é uma de suas características mais sobressalentes. Qual é o lugar do poeta nessa corrente de ar? Qual a sua posição nessa encruzilhada de saídas e entradas? A consciência do acesso a nada que ultrapasse o espectro do espetáculo - salvo na catástrofe, a cultura dominante da América Latina parece que não pode renunciar à sua situação de testemunho de um espetáculo que sempre ocorre em outra parte, mesmo que possa estar acontecendo precisamente aqui e agora e que com toda a pontualidade difunde-se aqui - obriga a uma marginalidade em pasmo. Da mesma maneira, qualquer acontecimento que ocorre aqui está sendo difundido como se estivesse acontecendo em outra parte. A afirmação midiática de nosso território é possível somente se nosso território for concebido como ponto de catástrofe. Seria bom pensar, como latino-americanos e como poetas latino-americanos, qual a verdadeira realidade de nossos feitos e qual é o 
reconhecimento real deles, para lá de nossos meios ainda muito autocentrados, que se lhes atribui.

4. Do mesmo modo que me parece falsa a globalização do ponto de vista em sua tradução conceitual de pretender ser, "de fato", o "mundo para todos" que estaríamos vivendo, é necessária, porém, a consciência do nosso ponto de vista como ponto, senão marginal, ao menos "ladeado", ligeiramente inclinado, que permite o autoquestionamento permanente do nosso próprio ponto de vista. Isso possibilita duas coisas: uma, não escorregar com relação à nossa verdadeira situação como poetas latino-americanos, a um mundo em que a diferença não é um sinal dado por uma prática alternativa - enquanto própria - da existência, mas, ao contrário, está indicado pelo maior ou menor alcance de inserção na circulação mundial. A assunção de uma consciência que se comporte desse modo é uma assunção de uma consciência alerta, atenta ao seu comportamento. Esse cenário, cruzamento entre consciência e ponto de vista, não é uma encruzilhada: é o estado em que se encontra quem lê pelo prisma das vanguardas, seja ou não praticante de procedimentos ainda assimilados ao que as vanguardas históricas desencadearam - experimentação lingüística, crítica da tradição, etc. Às vezes, em meio à loucura da ação com que se concebem as vanguardas, esquece-se que o salto de historicidade liberado por esse processo permite a sua reativação como modo de ler: ler pelo prisma das vanguardas seria ler pelo prisma de uma luz dilatada, um prisma que subtrai o impacto da luz, ler não a partir da opulência, mas da retração.

5. Sobre a auto-indulgência real com que fazemos poesia na América Latina, vista a partir da Europa, quero dizer algo: é certa. Não sabemos o que fazer. Mas há uma duração em jogo. A Europa é um mundo em continuidade. Na América Latina escrevemos sobre a descontinuidade. A imagem nunca superada pela Europa da vanguarda como promessa de ruína os fez, por contradição, superar/integrar a vanguarda. Entre nós a vanguarda encarnou como nascimento, e até agora não pudemos aceitá-la. São processos de escritura, um, o europeu, sustentado sobre o sedimento do sólido, outro, o latino-americano, sem sustentação, mantendo o equilíbrio sobre o precário, sobre o "precariato" do escombro. Isso se pode entender desde a 
Europa como escritura a propósito não-acabada? Pode-se assimilar como escolha? O que é um poema para nós? Pode-se perguntar isso? O que é um poema para a Espanha?

6. Uma das preocupações que saltam da comprovação do uso das armas críticas como elementos de legitimação da situação atual ("a única que há"), recordar Adorno: "A crítica não fere porque dissolve - isto é, pelo contrário, o melhor dela - senão na medida em que obedece às formas de rebelião". Não é difícil comprovar no mundo intelectual de hoje (mesmo que as práticas e as razões variem de um hemisfério a outro) a existência de uma pseudocrítica, essa que usa o arsenal, o vocabulário, a sintaxe e até a terminologia de determinada crítica de outro tempo histórico, gulosa pela linguagem que utiliza, perdido já o seu objeto ou obliterado por uma censura assumida de antemão: a que provém dos meios de difusão, a que provém da realidade da situação intelectual, a que provém da realidade da situação sociopolítica. Isso, a identificação do "objeto crítico" ou "objeto da crítica", é decisivo. Ainda que a crítica sirva para tudo, é possível sempre e quando se tiver identificado o objeto e o objetivo de sua ação. Ante a pergunta pela situação da arte, o intelectual não pode responder como um carpinteiro (profissão, entre todas, de prestígio supra-sensível): deve responder como intelectual. Quando se percebe o cansaço de certos exemplares intelectuais ante certas perguntas - devido à situação de esgotamento dos questionamentos mesmos, no melhor dos casos, ou da falta de horizonte em sua área de trabalho - e seu esquecimento dos problemas, respondendo-as utilizando-se do sentido o mais comum, estamos no terreno de uma disfunção evidente: o que responde está fora de lugar. Se diante de uma pergunta específica eu responder como qualquer pessoa não experimentada, minha resposta pode ser tão válida como a de qualquer outra, ou melhor, minha resposta não é qualificada. A desqualificação é ao que chegamos com as práticas pseudocríticas de função legitimadora. Isso é um problema que diz respeito diretamente à poesia. Pergunta: que função cumpre a crítica de poesia? Não pergunto o que é. Cumpre uma função diferente de outro objeto de crítica, dada a especificidade do objeto poético? As áreas aqui de novo se separam. Há um cultivo "específico" da crítica de poesia no âmbito acadêmico: o ambiente é relaxado, há orçamento para 
uma das belas-letras, há espaço e, com sorte, espaço verde. Há universidades que vêm abaixo. Uma vez, há alguns anos, entrei na Faculdade de Letras da Universidade de São Paulo. Passei por um banheiro. Entrei. Pareceu-me haver entrado em um banheiro da Faculdade de Humanidades da UNAM, no México. O mesmo descuido, a mesma carência. Os banheiros universitários diferem pouco dos banheiros das prisões. Estão em pior estado que algumas celas de presos políticos. Mas em geral - sempre na América Latina - se pode observar uma diferença entre os espaços habitáveis de uma Faculdade de Humanidades e uma Faculdade de Engenharia, por exemplo - e de uma Faculdade de Economia, nem se fale. Há 50 anos o espaço de uma cozinha era a medida habitável de um lugar. Hoje é um banheiro. Há que se entrar em um banheiro de qualquer instituição educativa pública da América Latina para saber em que estamos parados. Do outro lado da rua, a crítica jornalística dificilmente pode ser considerada como tal. É possível fazer crítica de poesia em um jornal? Mallarmé pensou o poema-jornal, não a crítica-jornal. Que a modernidade arrasou a utopia da modernidade todo mundo sabe. Entre as revistas periódicas, equilibradamente. No geral, pode-se dizer que, na América Latina, um poema medianamente bem-feito é superior a uma crítica da mesma medida.

7. Por último, ante a brutal contradição que vivemos hoje entre, de um lado, a prática produtiva como afirmação de uma necessidade de consumo e bemestar e, por outro, a negação também prática das possibilidades vitais de três quartos da população mundial legitimada pelo modelo excludente do sistema atual, pode-se perguntar, e ainda que pareça estranho, que significação adquire a arte atual em face da coexistência da totalidade dos repertórios formais. Uma resposta à exclusão sistemática da maioria da população mundial diante da possibilidade de coexistência artística de formas, metáforas e de outras formas, as de existência real? A mais banal representação de uma crise terminal de pensamentos formais, se não evolutivos, mas progressivos? O que essa coexistência faz explodir é a possibilidade crítica, atravessada por uma intervenção de caráter ético que proscreve a ação da questão posta e relega a crítica a mero discernimento. E, de forma mais brutal, o que a coexistência de formas deixa intacta é a lógica produtivo-quantitativa aplicada à arte. 